\title{
INTERFACE SINTAXE-FONOLOGIA: DESAMBIGUAÇÃO PELA ESTRUTURA PROSÓDICA NO PORTUGUÊS BRASILEIRO ${ }^{1}$
}

\author{
Aline Peixoto GRAVINA* \\ Flaviane Fernandes-SVARTMAN**
}

- RESUMO: O objetivo deste artigo é a análise das estratégias prosódicas de desambiguação de sentenças em português brasileiro (PB), em contexto de ambiguidade sintática e choque acentual. ${ }^{2}$ Nossa hipótese é a de que a desambiguação dessas sentenças se dê através de diferentes estratégias prosódicas de desfazimento do choque acentual. Para testar essa hipótese, foram realizados experimentos de produção e de percepção com falantes do PB. Os resultados obtidos foram analisados à luz da Fonologia Prosódica (NESPOR; VOGEL, 1986) e, em termos entoacionais, à luz da Fonologia Entoacional (PIERREHUMBERT, 1980; LADD, 1996, 2008). Nossos resultados revelam que: (i) quando o desfazimento do choque de acentos se dá por retração acentual, há pistas da formação de um único sintagma fonológico e a interpretação é a de que a segunda palavra envolvida no choque se refere à imediatamente precedente; (ii) quando o desfazimento do choque se dá pela inserção de pausas e/ou pela atribuição de um acento tonal a cada palavra envolvida no choque, há pistas da formação de dois sintagmas fonológicos e a interpretação obtida é a de que a segunda palavra envolvida no choque se refere não à imediatamente precedente, mas à outra da sentença.

- PALAVRAS-CHAVE: Português brasileiro. Interface sintaxe-fonologia. Prosódia. Choque de acentos.

* UNICAMP - Universidade Estadual de Campinas. Instituto de Estudos da Linguagem. Campinas - SP - Brasil. 13083-859 - alinegravina@yahoo.com.br

** USP - Universidade de São Paulo. Faculdade de Filosofia, Letras e Ciências Humanas. São Paulo - SP - Brasil. 05508-900 - flavianesvartman@usp.br

1 Este trabalho é resultado do desenvolvimento de uma qualificação de área, um dos requisitos exigidos pelo Programa de Pós-Graduação do Instituto de Estudos da Linguagem da Universidade Estadual de Campinas para a obtenção do título de Doutor. Tal qualificação foi desenvolvida pela primeira autora deste artigo e orientada pela segunda.

2 Por "ambiguidade sintática", entenda-se: sentenças que possuem mais de uma estrutura sintática subjacente. Por exemplo, uma sentença como "Escrevi no quadro negro" possui mais de uma estrutura sintática subjacente e, por esse motivo, permite duas interpretações diferentes. Se se considerar que "negro" é o objeto do verbo "escrevi" e "no quadro", adjunto adverbial, a interpretação obtida é a de que escrevi o nome "negro" no quadro. Já se se considerar "negro" como adjetivo de "quadro", a interpretação obtida é a de que escrevi em um quadro de cor negra. A ambiguidade sintática difere da ambiguidade semântica e da ambiguidade fonológica, na medida em que, na ambiguidade semântica, a interpretação pode depender de um contexto (ex.: "Encontrei o cachorro do seu vizinho". Dependendo do contexto, o cachorro pode ser o próprio vizinho ou o animal de estimação do vizinho) e, na ambiguidade fonológica, a semelhança sonora na produção de, por exemplo, uma palavra ou um grupo de palavras pode permitir mais de um sentido (ex.: "abata" (1 $1^{\mathrm{a}}$. ou $3^{\mathrm{a}}$. pessoa do singular do presente do subjuntivo do verbo "abater") e "a bata" (peça do vestuário feminino). 


\section{Introdução}

Neste artigo, trataremos de fenômenos de interface sintaxe-fonologia, a partir do estudo de sentenças com choque de acentos em ambiente de ambiguidade sintática no português brasileiro (doravante, PB). A partir da análise desses dados do PB, obtidos através da aplicação de experimentos de produção e percepção, pretende-se discutir os seguintes tópicos: (i) o fenômeno "choque de acentos", em ambiente de ambiguidade sintática, e suas possibilidades de ocorrência no interior de domínios prosódicos, especificamente, o domínio "sintagma fonológico" $(\phi \text { - do inglês, phonological phrase) })^{3}$ e entre fronteiras desses domínios; ${ }^{4}$ (ii) o desfazimento de choque de acentos no mesmo ambiente já referido, através de diferentes estratégias, entre elas, a regra de retração de acento (ex.: canção nova $\Rightarrow$ canção nova). ${ }^{5}$

Para o desenvolvimento da discussão desses tópicos, buscaremos evidências perceptuais e acústicas (especificamente, nos correlatos acústicos "entoação" e "duração") para a mudança do locus do acento em PB (nos casos em que ocorrer esse deslocamento) e investigaremos a relação das diferentes estratégias de desfazimento de choque de acentos com a desambiguação de sentenças em que há contexto para a ocorrência de choque de acentos.

A nossa hipótese é que a desambiguação das sentenças selecionadas para o estudo possa ocorrer através do estabelecimento de fronteiras de sintagmas fonológicos. A ocorrência de retração de acentos, em um ambiente de ambiguidade sintática, favoreceria a interpretabilidade de que o segundo vocábulo envolvido no choque de acentos se relacionaria ao primeiro, uma vez que esses formam um único sintagma fonológico; já a não ocorrência de retração de acentos, em um ambiente de ambiguidade sintática, daria pistas para a identificação de formação de dois sintagmas fonológicos diferentes, sendo que a interpretação obtida seria aquela conforme a qual o segundo vocábulo não estaria relacionado ao primeiro do contexto de choque de acentos, mas a outro vocábulo da sentença à qual pertence.

O presente trabalho será apresentado nas próximas cinco seções. Na seção "O choque de acentos" apresentamos uma revisão dos primeiros trabalhos que trataram desse assunto. Em seguida, na seção "Choque e retração de acentos em português brasileiro", revisamos os trabalhos do português brasileiro que trataram da questão do choque e da retração de acentos na vertente teórica gerativista. Já na seção "Experimento: prosódia e desambiguação" são

3 Conferir Nespor e Vogel (1986) sobre o algoritmo de formação de sintagma fonológico e, especificamente, Frota (2000) e Tenani (2002) sobre o algoritmo de formação desse constituinte em português.

4 O constituinte fonológico alvo de nossas análises será o sintagma fonológico ( $\phi$ ), pois o fenômeno de choque de acentos em PB encontra-se nesse nível da hierarquia prosódica, conforme, entre outros, Abousalh (1997) e Sandalo e Truckenbrodt (2002).

5 As sílabas sublinhadas representam sílabas nas quais o acento é implementado foneticamente. 
apresentadas a metodologia de obtenção dos dados, através da elaboração e aplicação de dois testes - produção/percepção -, bem como a metodologia de análise dos dados obtidos. Por sua vez, nas seção "Resultados e Análises", apresentamos a descrição e a análise dos resultados encontrados. Finalmente, na seção "Considerações finais", apresentamos as conclusões a que chegamos neste presente estudo.

\section{O choque de acentos}

O trabalho de Liberman e Prince (1977) foi um dos primeiros que tentou caracterizar e representar o fenômeno do choque de acentos. Os autores observaram que as relações de proeminência relativa interna às palavras tendem a se manter constantes sob concatenação sintática. Assim, buscaram explicar por que, em inglês, dadas algumas condições específicas, o padrão acentual resultante da aplicação do algoritmo de acento primário pode ser modificado na implementação fonética.

Os autores observaram que, quando duas palavras estão concatenadas sintaticamente uma a outra, sendo que a última sílaba da primeira palavra porta um acento de força relativa de igual ou maior valor que o acento da sílaba inicial da palavra seguinte, a tendência é que ocorra uma reversão acentual, ou seja, o acento da primeira palavra transfere-se para a penúltima ou para a antepenúltima sílaba. Para esses autores, a mudança de locus do acento parece ter uma motivação de ordem rítmica e tem sido explicada pela aplicação de uma regra chamada de rhythmic rule. Essa regra seria de ajuste rítmico pós-lexical que ocorreria em contextos de choque de acentos dentro do sintagma fonológico $(\phi)$ e, conforme a qual, o acento primário de uma palavra seria movido para esquerda ou apagado quando não houvesse contexto para o movimento.

Nespor e Vogel (1989) realizaram um experimento à luz da proposta de Liberman e Prince (1977) e concluíram em seus estudos que, sem a inclusão de informações de constituição sintática na descrição dos contextos de choques, não se podem fazer previsões corretas sobre a resolução dos choques de acento em italiano.

Dessa forma, é preciso que haja condições fonológicas e sintáticas para que seja considerada uma colisão de acentos. A condição fonológica, segundo as autoras, para que ocorra o choque de acentos é a seguinte: em uma sequência de palavra 1 e palavra 2, o acento primário da palavra 1 tem que estar na sua sílaba final e o acento primário da palavra 2, na sua sílaba inicial. No entanto, a simples adjacência fonética de acentos fortes não é suficiente para caracterizar um choque de acento, dado que as condições sintáticas também devem ser 
respeitadas. Assim, em uma situação de choque de acento, entre a palavra 1 e a palavra 2, é necessário que 1 seja "ramo" do primeiro nódulo da árvore sintática que domine ela mesma e a palavra 2. Satisfeitas as duas condições, a retração ocorre em 1, no caso em que as palavras envolvidas no choque formam um único sintagma nominal, por exemplo.

O sintagma fonológico ( $\phi$ ) seria, para Nespor eVogel (1982), o domínio de regras fonológicas em várias línguas do mundo. Uma das regras que se aplica nesse domínio é a regra de retração de acento. Conforme essa regra, numa sequência de acentos primários em choque, para se desfazer a colisão, movimenta-se o acento da primeira palavra envolvida no choque para a esquerda, se as duas palavras em questão fizerem parte de um mesmo sintagma fonológico. A retração é bloqueada se as palavras estiverem em sintagmas fonológicos distintos. Em outras palavras, no domínio prosódico "sintagma fonológico $(\phi)$ ", a retração de acento é incluída como uma regra de spam de $\phi$, ou seja, uma regra cujo domínio de aplicação corresponde ao espaço delimitado pelas fronteiras de $\phi$.

Seguem alguns exemplos das autoras:

(1) Ha giá [véntitre rágni] (Ele) já possui vinte e três aranhas.

(2) [Le cittá] $]_{\phi}[\text { mollto nordiche }]_{\phi}$ no mi piacciono. As cidades muito nórdicas não me agradam.

Em (1), ocorre a retração de acento para desfazer a colisão de acentos em um mesmo sintagma fonológico. O acento da palavra "ventiré" vai para a sílaba mais à esquerda "ven", para que se desfaça o choque. Em (2), o choque de acentos se conserva, pois as palavras que sofrem a colisão se encontram em sintagmas fonológicos distintos, desrespeitando a condição fonológica para que a retração ocorra. Como podemos notar, a regra de retração, aos moldes de Nespor; Vogel, serve também como diagnóstico da reestruturação de sintagmas fonológicos.

\section{Choque e retração de acentos no português brasileiro}

O acento para a prosódia é uma propriedade relacional, logo, a acentuação é analisada numa relação entre sílabas acentuadas e sílabas não acentuadas, apontando proeminências. De acordo com o Princípio de Alternância Rítmica (SELKIRK, 1984) e com as Regras Rítmicas (TAKEZAWA, 1981), deve-se evitar o choque de acentos em uma sentença linearizada, uma vez que os princípios acima supracitados requerem que, em uma situação de duas posições de acento, apenas uma posição sobressaia e apenas uma seja não acentuada. Nespor eVogel 
(1982) ainda ressaltam que as línguas se diferenciam a partir da tolerância que apresentam com relação à violação desses princípios.

Frota (1995) e Albousalh (1997) afirmam que o português (respectivamente, nas variedades europeia e brasileira) é sensível ao encontro acentual dentro do nível que, na sua formação, leva em conta informações sintáticas. Isso implica dizer que o PB, conforme Albousalh, é sensível ao encontro acentual no nível do sintagma fonológico $(\phi)$.

Nesse mesmo nível prosódico em PB, segundo Santos (2002), categorias sintáticas foneticamente nulas parecem afetar a ocorrência da retração no desfazimento de choque acentual. Mais precisamente, a autora mostrou que um pronome foneticamente nulo (pro) pode impedir a retração de acento nos casos de encontro acentual entre um verbo e um advérbio.

(3)

a O José Maria cantou hoje.

b. O José Maria contou hoje.

a') O José Maria cantou hoje.

b') *O José Maria contou hoje.

Em (3a) e (3a'), tanto o encontro de choque de acentos quanto a retração do acento são possíveis; já em (3b') a retração do acento não é possível e apenas a colisão em (3b) é aceita. Isso porque haveria um pronome foneticamente não realizado (pro) entre o verbo "contou" e o advérbio "hoje". Logo, uma categoria sintática não realizada foneticamente, como um pronome nulo "pro", entre um verbo com acento final e um advérbio com acento na primeira sílaba, não permite que o choque de acentos seja desfeito, ou seja, a retração de acento torna a sentença agramatical.

Ainda sobre o domínio de aplicação da retração de acentos em contexto de choque acentual em PB, Sandalo e Truckenbrodt (2002) também afirmam que o sintagma fonológico é o domínio relevante para essa regra rítmica de resolução de choque de acentos e, como notado primeiramente por Frota e Vigário (2000) e por Tenani (2002), para a associação de acentos tonais. Os autores explicitam que o fenômeno da retração de acento no PB ocorre de maneira comparável ao English rhythmic-rule (LIBERMAN; PRINCE, 1977) ou à retração de acento estipulada para o italiano por Nespor e Vogel (1982, 1986, 1989).

Para exemplificar, os autores mostram que a palavra "café", pronunciada isoladamente, possui o acento fonológico na mesma sílaba em que possui acento ortográfico. No entanto, quando essa palavra se encontra em contexto de choque de acentos como em "café quente", ela sofre uma retração de acento para a sílaba da esquerda, resultando em "café quente".

Sandalo e Truckenbrodt (2002) confirmam os resultados obtidos por Nespor e Vogel (1989) para o italiano também para o PB, na medida em que atestam que, 
nessa variedade de português, a retração de acento só pode ocorrer se o choque de acentos se der dentro de um mesmo sintagma fonológico: ex.: [café quente] ${ }_{\phi}$. Se o choque de acentos ocorrer entre palavras pertencentes a sintagmas fonológicos

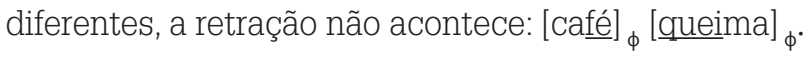

Os autores seguem a proposta de Selkirk (1986) para fundamentar hipóteses sobre o PB. Segundo a proposta de Selkirk, o mapeamento sintaxe-fonologia na formação dos constituintes prosódicos se dá de maneira universal nas línguas e a diferença entre elas em tal formação se dá conforme as particularidades do encaixamento sintático. O alinhamento à esquerda de XPs com sintagmas fonológicos tem sido postulado para línguas como o chinês (SELKIRK; SHEN, 1990) e o japonês (SELKIRK; TATEISHI, 1991). Para línguas como o inglês, o italiano e o português, tem se postulado o alinhamento à direita. Portanto, a fronteira direita de cada XP lexical coincide com a fronteira direita do sintagma fonológico no PB.

Cada XP pode ser mapeado em apenas um sintagma fonológico. Sendo assim, sujeito e verbo no PB são mapeados em sintagmas fonológicos distintos. O choque de acentos entre esses constituintes não é desfeito por retração acentual, pois, como dito anteriormente, a retração só ocorre dentro de um mesmo sintagma fonológico $(\phi)$.

Os autores ainda seguem o princípio da uniformidade postulado por Ghini (1993) para formação de sintagma fonológico e testam para o PB tal princípio, através da análise da ocorrência ou não de retração de acentos no referido domínio prosódico. Em suas investigações em italiano, Ghini argumenta que a reanálise de sintagma fonológico, em termos de fatores eurrítmicos, abarca a noção de binaridade prosódica e esta noção seria o núcleo das análises. Assim, no PB, a hipótese de Sandalo; Truckenbrodt é que o fraseamento prosódico do sujeito e do predicado ocorre por motivação de fatores eurrítmicos de uniformidade do comprimento dos sintagmas fonológicos desses dois constituintes sintáticos. Os exemplos (4) e (5), extraídos de Sandalo e Truckenbrodt (2002, p.298), ilustram o obedecimento ao princípio de uniformidade de Ghini na formação de sintagmas fonológicos do sujeito e do predicado em sentenças do PB. Em (4), o sujeito, composto por duas palavras prosódicas, é mapeado em um único sintagma fonológico, assim como o predicado, formado por duas palavras prosódicas em contexto de choque acentual, também é mapeado em um único sintagma fonológico e, nesse caso, a evidência para o mapeamento do predicado em um único sintagma fonológico é a retração de acentos. Em (5), as duas palavras que compõem o sujeito se encontram em contexto de choque acentual e pertencem a sintagmas fonológicos diferentes, sendo que a evidência para isso é a não ocorrência de retração acentual. No mesmo exemplo, o predicado composto por uma única palavra é mapeado também em um único sintagma fonológico. Assim, tanto sujeito quanto predicado em (4) e (5) são formados por sintagmas fonológicos de mesmo tamanho (no caso, com o mesmo número de palavras prosódicas). 
(4) [o canguru australiano $]_{\phi}\left[\underline{\text { dançou samba }]_{\phi}}\right.$

(5) [café $]_{\phi}[\text { quente }]_{\phi}[\underline{\text { queima }}]_{\phi}$

O princípio da uniformidade rege que os sintagmas fonológicos sejam do mesmo tamanho. Dessa maneira, alinhando as sentenças à direita e seguindo o princípio da uniformidade, temos o seguinte fraseamento prosódico para as sentenças em (6) e (7) extraídas de Sandalo e Truckenbrodt (2002, p.301):

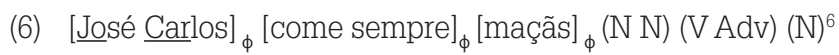

(7) $[\mathrm{Um} \text { café quente] }]_{\phi}[q u e i m o u \text { a boca }]_{\phi}[o n t e m]_{\phi}(\mathrm{N}$ A) (V N) (Adv)

Os autores postulam que, no PB, cada sintagma fonológico é formado por, no máximo, duas palavras lexicais. Assim, uma sequência como (V N Adv) ${ }_{\phi}$, ou parecida, é impossível.

Neste trabalho, não trataremos apenas de choque de acentos e retração acentual em PB, mas de choque de acentos em contexto de ambiguidade sintática e das diferentes estratégias prosódicas de desfazimento do choque e de desambiguação nessa variedade de português. Pretendemos mostrar que, em um contexto de choque de acentos e ambiguidade sintática, são possíveis as seguintes situações: i) ocorrer a retração de acentos e esta possibilidade corresponder a um dos sentidos possíveis pelo contexto de ambiguidade sintática; ii) não ocorrer a retração de acento e esta possibilidade corresponder ao outro sentido possível pelo contexto de ambiguidade. Ainda é objetivo do presente trabalho a investigação das pistas acústicas das estratégias prosódicas de desfazimento do choque de acentos e de desambiguização sintática.

\section{Experimento: prosódia e desambiguação}

Na busca pelo alcance dos objetivos do presente trabalho, realizamos um experimento que consistiu na elaboração e aplicação de dois tipos de testes: teste de produção e teste de percepção. Inicialmente, foram gravados três informantes produzindo quinze sentenças com choque de acentos. Cada informante produziu as sentenças duas vezes, mas foi instruído para que cada leitura representasse uma interpretação diferente, ou seja, o informante teve acesso à informação de que as sentenças eram ambíguas e quais as possíveis interpretações para cada uma delas.

Os autores identificam N como noum (substantivo); V como verb (verbo); Adv como adverb (advérbio) e A como adjective (adjetivo). 
Para que houvesse uma confiabilidade ainda maior nos resultados, realizamos esse mesmo procedimento com esses mesmos informantes três meses depois da primeira gravação. Isso, com o intuito de observar se o informante se utilizaria das mesmas técnicas e estratégias de produção para desambiguar as sentenças propostas nesse experimento.

Os três falantes de PB (L, B e P) que realizaram o experimento de produção são provenientes do estado de São Paulo, pertencem à mesma faixa etária (24 a 27 anos), possuem o mesmo grau de escolaridade (nível universitário), além de mesmo sexo (feminino). A área de formação de cada uma delas é diferente: L é graduada em Educação Física, B é graduada em História e P é graduada em Letras. A opção por informantes de áreas distintas foi intencional, com o propósito de averiguar se haveria alguma influência no resultado das interpretações. Para realizar as gravações, foi feito uso de um gravador digital Panasonic, modelo US 360, a $16 \mathrm{kHz}$.

Após as gravações, as sentenças produzidas foram analisadas acusticamente, com o uso do programa computacional de análise da fala PRAAT (BOERSMA; WEENINK, 2010). A análise acústica desse trabalho baseou-se em dois procedimentos: medição de duração de sílabas e transcrição de eventos tonais das sentenças, conforme o quadro teórico da Fonologia Entoacional (PIERREHUMBERT, 1980; BECKMAN; PIERREHUMBERT, 1986; LADD, 1996, 2008; JUN, 2005; e, especificamente para o PB, FROTA; VIGÁRIO, 2000; TENANI, 2002; FERNANDES, 2007) ${ }^{7}$. A análise acústica teve por finalidade a busca de correlatos acústicos que fornecessem pistas para a identificação da estratégia prosódica utilizada pelos falantes para: (i) garantir determinada interpretação na produção de uma sentença com mais de uma interpretação possível; e (ii) evitar o choque entre acentos. Investigamos ainda se o tipo de estratégia prosódica escolhida pelos falantes para garantir determinada interpretação na produção de uma sentença ambígua também estava relacionado ao tipo de estratégia escolhida para evitar o choque entre acentos.

As quinze (15) sentenças ambíguas produzidas e analisadas acusticamente foram as seguintes 8 :

7 A escolha pela Fonologia Entoacional (simplificação, aqui utilizada, para "Fonologia Entoacional Autossegmental-Métrica (AM)" - cf. Ladd $(1996,2008)$ para a análise entoacional realizada neste trabalho foi feita com base na adequação desse modelo teórico ao propósito de se analisar eventos tonais de uma perspectiva fonológica. Por sua vez, ainda cabe acrescentar que a escolha pela Fonologia Prosódica (cf. SELKIRK, 1984, 1986, 2000; NEPOR; VOGEL, 1986; entre outros), teoria também utilizada na análise de nossos dados, justifica-se na medida em que a hipótese deste trabalho (cf. seção "Introdução") remete ao fraseamento da cadeia segmental em domínios prosódicos, objeto de análise, por excelência, da Fonologia Prosódica.

8 É importante ressaltar que as 15 sentenças aqui selecionadas não seguiram um critério de uniformidade de sílabas no ambiente de choque de acentos. As palavras que podem sofrer "retração de acento" no contexto de ambiguidade são monossílabas, dissílabas e trissílabas. Portanto, quando há monossílabas envolvidas no choque acentual, após a retração, o acento recai na palavra anterior, como por exemplo, na sentença (14), na qual o acento da palavra "fé" passa para a preposição "de", de acordo com nossa hipótese. Já nas palavras 

1) Assisti ao jornal hoje.
2) Encontrei o professor de balé russo.
3) Eu vi o aluno de francês fraco.
4) Conheci a cantora da canção nova.
5) Vi a Maria na TV muda.
6) A gelatina ficou sobre o mocotó mole.
7) Vi o garoto do cão bravo.
8) O rapaz caiu no chão duro.
9) O marinheiro deu um nó cego.
10) Ela encontrou o gato no canal sujo.
11) Ele bateu o cadeado no portão torto.
12) O menino escreveu no papel pardo.
13) Ele encontrou o vendedor de sofá persa.
14) Joana achou o musculoso de fé forte.
15) João acudiu o marajá branco.

Para o teste de percepção, foram utilizadas as gravações realizadas pelos informantes do teste de produção e também foram incluídas algumas sentenças distratoras, para que o sujeito, ao realizar o teste de percepção, não percebesse o objetivo real do teste e, desse modo, não obtivéssemos resultados enviesados.

Foi pedido a 10 falantes do PB para que escutassem e apontassem as possíveis interpretações dessas sentenças. Diferentemente do teste de produção, no teste de percepção, os falantes não foram informados sobre as possíveis interpretações das sentenças que foram escutadas por eles. Apenas lhes foi solicitado para apontar o sentido que achassem ser o mais adequado à sentença ouvida.

O teste de percepção foi realizado por cada um dos 10 informantes individualmente, em um ambiente silencioso. As frases foram apresentadas em slides Power Point com áudio referente às diferentes produções realizadas pelas três informantes do teste de produção para cada interpretação possível para cada uma das sentenças ambíguas. O informante pôde ouvir a sentença mais de uma vez sem um limite de tempo para passar para outra sentença. Ao definir o sentido da sentença, marcava, com um "x", a interpretação que julgava adequada. As sentenças selecionadas apareciam de forma aleatória e, a cada cinco sentenças, apareciam sentenças distratoras intercaladas.

A seguir, tem-se um exemplo de slide apresentado aos informantes. Para executar a tarefa, era preciso ouvir o arquivo de som, acessando o ícone amarelo (abaixo das alternativas) e, após a audição, marcar, com um "x", a explicação considerada pertinente para o julgamento então efetuado:

trissílabas envolvidas no choque acentual, como a palavra "marajá" da sentença (15), por exemplo, após a retração, o acento não recai na segunda sílaba, mas, sim, na primeira sílaba dessa palavra, assim, temos "máraja" e não "marája". Seguimos aqui Nespor e Vogel (1986) (conferir exemplo (1) deste trabalho). 
Figura 1 - Modelo de slide apresentado para os informantes

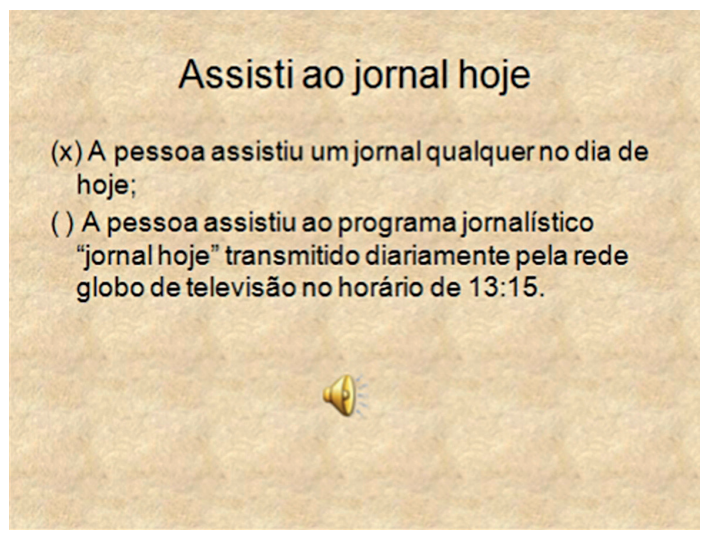

Fonte: Elaboração própria.

Foi apresentado um total de 36 slides para cada informante: as 15 sentenças ambíguas, produzidas duas vezes, conforme as diferentes interpretações possíveis, pelas falantes do experimento de produção, mais 3 sentenças distratoras (sendo apresentadas duas vezes cada uma).

\section{Resultados e análises}

\section{Teste de produção}

De maneira geral, os resultados obtidos pelo teste de produção revelam que, em uma situação de choque de acentos, em um ambiente ambíguo, a desambiguação pode ocorrer sob uma das seguintes formas:

i. Quando a retração de acentos acontece, as duas palavras envolvidas no choque de acentos formam apenas um sintagma fonológico e o segundo vocábulo se relaciona à primeira palavra. Por exemplo, em Assisti aojornal hoje, há retração do acento da palavra "jornal", o que indica que "jornal" e "hoje" pertencem ao mesmo sintagma fonológico, e o sentido associado a essa estrutura é que foi assistido a um programa jornalístico chamado Jornal Hoje.

ii. Quando a retração não ocorre, como estratégia de evitar o choque de acentos, tem-se a formação de dois sintagmas fonológicos distintos para "jornal" e "hoje" e a interpretação é outra. Por exemplo, a mesma sentença Assisti ao jornal hoje, pronunciada sem a retração de acento, está associada à interpretação de que se teria assistido qualquer jornal no dia de hoje.

Passemos à apresentação mais detalhada e à discussão de nossos resultados. 
Abaixo, apresentaremos as figuras contendo forma de onda e contorno entoacional referentes às produções da sentença Assisti ao jornal hoje. A primeira figura representa a produção de "jornal hoje", conforme a interpretação de "Jornal Hoje" (JORnal HOje) $\phi$ como um único nome, ou seja, o nome de um programa jornalístico veiculado na televisão. Já a segunda figura representa a produção da mesma sentença com a interpretação de (jorNAL) $\phi$ (HOje) $\phi$ como duas palavras com classificações morfológicas diferentes, a primeira como substantivo e a segunda como advérbio.

Figura 2 - Contorno entoacional e forma de onda da sentença Assisti ao jornal hoje, produzida por L para [jornal hoje] $\phi$

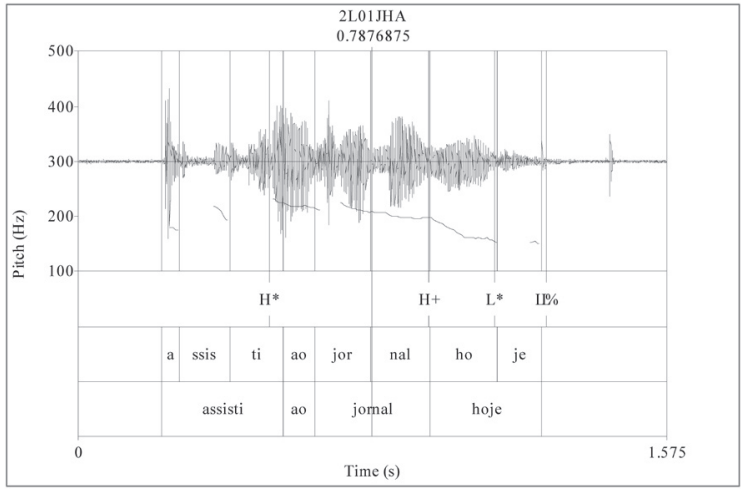

Fonte: Elaboração própria.

Figura 3 - Contorno entoacional e forma de onda da sentença Assisti ao jornal hoje, produzida por L para [jornal] $\phi$ [hoje] $\phi$

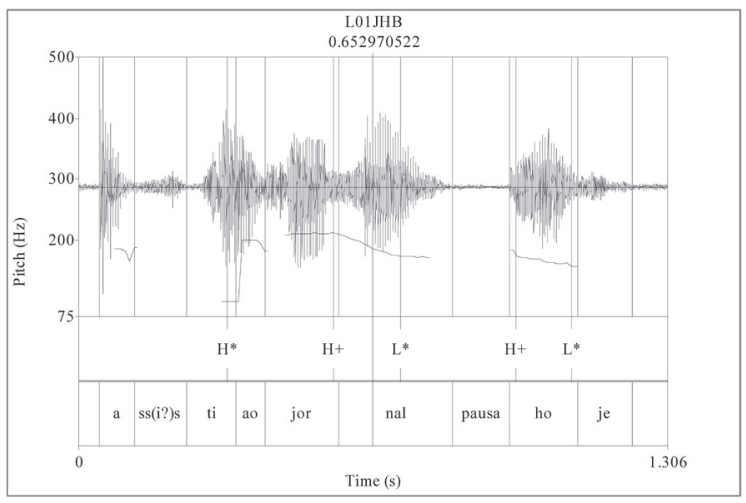

Fonte: Elaboração própria. 
Através da observação da figura (3), nota-se que a informante (L), na produção da sentença Assisti ao jornal hoje, além de não realizar a retração acentual em "jornal", conforme nossa percepção auditiva, utilizou o recurso da pausa para identificar que hoje, no valor de advérbio, está em um sintagma fonológico diferente de onde se encontra a palavra jornal. Já na produção de jornal hoje como um único sintagma fonológico, cuja evidência é a retração acentual na palavra "jornal", há a atribuição de apenas um acento tonal $\left(\mathrm{H}+\mathrm{L}^{*}\right)$ à palavra fonológica cabeça, respectivamente, "hoje”, do sintagma fonológico (jornal hoje)ф.

Agora, observemos as figuras representativas das produções da mesma sentença pela segunda informante (B):

Figura 4 - Contorno entoacional e forma de onda da sentença Assisti ao jornal hoje, produzida por B para [jornal hoje] $\phi$

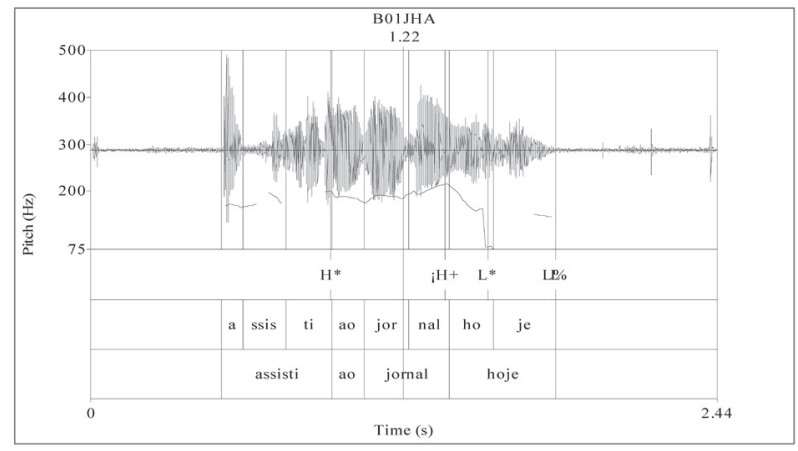

Fonte: Elaboração própria.

Figura 5 - Contorno entoacional e forma de onda da sentença Assisti ao jornal hoje, produzida por B para [jornal] $\phi$ [hoje] $\phi$

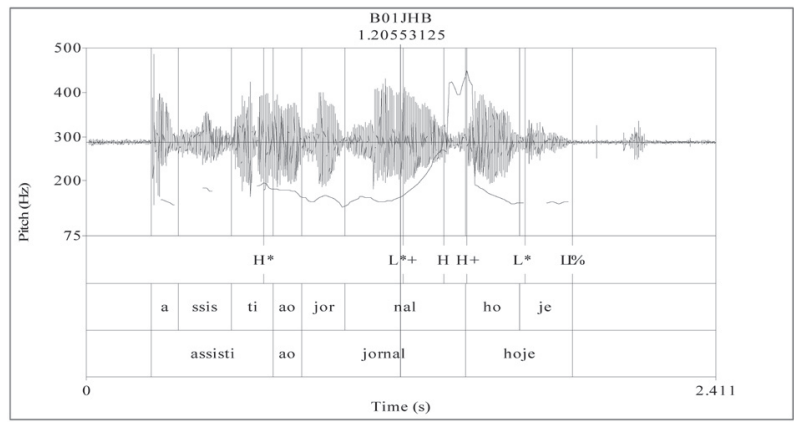

Fonte: Elaboração própria. 
Diferentemente da informante (L), a informante (B) não se utilizou de pausa para identificar o hoje da segunda sentença como advérbio. Mas utilizou a estratégia de atribuição de um acento tonal $\left(\mathrm{L}^{*}+\mathrm{H}\right)$ para "jornal" e outro $\left(\mathrm{H}+\mathrm{L}^{*}\right)$ para "hoje", o que também pode indicar, assim como notado para a primeira informante, mas em relação à estratégia de uso de pausa, a possibilidade de "jornal" e "hoje" formarem sintagmas fonológicos independentes. Nesse caso, a atribuição de um acento tonal para cada palavra envolvida no choque acentual pode ser uma evidência a mais, além da não ocorrência de retração acentual (conforme nossa percepção auditiva), para a formação de dois sintagmas fonológicos diferentes. Por outro lado, a primeira figura ilustra a ocorrência de apenas um acento tonal $\left(\mathrm{H}+\mathrm{L}^{*}\right)$ atribuído a "hoje", dando pistas de que jornal e hoje formam um único sintagma fonológico e, nesse caso, o acento tonal é atribuído obrigatoriamente à cabeça do sintagma fonológico (sobre a obrigatoriedade de atribuição de acentos tonais à cabeça de sintagma fonológico em PB, ver Frota e Vigário (2000), Tenani (2002), entre outros). Esse tipo de atribuição tonal se configura em uma evidência a mais, além da ocorrência de retração acentual em "jornal", por nós percebida, para a formação de um único sintagma fonológico formado por "jornal" e "hoje".

Para essa mesma sentença, a terceira informante, (P), utilizou-se das mesmas estratégias que a primeira informante. Ou seja, no sentido de hoje como advérbio, produziu uma pausa entre "jornal" e "hoje", além de não ter realizado retração acentual em "jornal". Já no sentido de "jornal hoje" como um único nome, além de termos percebido a realização de retração acentual em "jornal", observamos a atribuição de um único acento tonal à cabeça ("hoje") do sintagma fonológico composto por "jornal" e "hoje".

Os resultados ora apresentados representam as principais estratégias encontradas em nosso experimento para a desambiguização sintática e o desfazimento do choque de acentos: 1) a retração do acento no interior de um mesmo sintagma fonológico; e 2) a utilização de pausas ou a atribuição de um acento tonal para cada uma das palavras fonológicas envolvidas no choque de acentos. Tratando-se da estratégia 2), observou-se, pelas análises, que não houve uma uniformidade quanto ao uso de pausas ou atribuição de acentos tonais pelos informantes, uma vez que uma mesma informante ora utilizava o primeiro, ora utilizava o segundo recurso prosódico na produção de sentenças com o mesmo sentido. Para evidenciar esse uso de diferentes recursos prosódicos para a produção de um mesmo sentido, a seguir, encontra-se a tabela com os resultados dos diferentes usos dos recursos especificados em 2) e utilizados pelos informantes tanto na primeira, quanto na segunda gravação: 
Tabela 1 - Recursos prosódicos, diferentes da retração de acento, utilizados pelos informantes na desambiguação de sentenças e desfazimento de choque acentual

\section{Informante}

Uso de pausas

\section{Um acento tonal para cada palavra fonológica envolvida no choque de acentos}

\begin{tabular}{lcccccc}
\hline & $\begin{array}{c}\text { Número de } \\
\text { ocorrências } \\
\text { (primeira } \\
\text { gravação) }\end{array}$ & $\begin{array}{c}\text { Número de } \\
\text { ocorrências } \\
\text { (segunda } \\
\text { gravação) }\end{array}$ & Total & $\begin{array}{c}\text { Número de } \\
\text { ocorrências } \\
\text { (primeira } \\
\text { gravação) }\end{array}$ & $\begin{array}{c}\text { Número de } \\
\text { ocorrências } \\
\text { (segunda } \\
\text { gravação) }\end{array}$ & Total \\
\hline L & 6 & 6 & $\mathbf{1 2}$ & 9 & 9 & $\mathbf{1 8}$ \\
\hline B & 1 & 11 & $\mathbf{1 2}$ & 14 & 4 & $\mathbf{1 8}$ \\
\hline P & 12 & 11 & $\mathbf{2 3}$ & 3 & 4 & $\mathbf{7}$ \\
\hline & & & $\mathbf{4 7}$ & & & $\mathbf{4}$ \\
\hline
\end{tabular}

Fonte: Elaboração própria.

É interessante notar, conforme a observação da tabela, que, apesar de as informantes L e B terem apresentado o mesmo número total de ocorrências para cada recurso prosódico, a distribuição entre a primeira e a segunda gravação foi bem diferente. Enquanto L apresentou uma distribuição proporcional (idêntica em quantidade) dos diferentes recursos prosódicos utilizados na primeira e na segunda gravação, a informante B utilizou a pausa apenas uma vez na primeira gravação. Já na segunda gravação, a preferência dessa informante foi o uso de pausa. A informante P, tanto na primeira quanto na segunda gravação, apresentou preferência pelo uso de pausas.

Para ilustrar o fato de a mesma informante se utilizar de recursos prosódicos diferentes na produção de sentenças com o mesmo sentido, seguem, abaixo, as figuras relativas às produções da sentença Encontrei o professor de balé russo, realizadas pela informante (B), na primeira e na segunda gravação, respectivamente: 
Figura 6 - Contorno entoacional e forma de onda da sentença Encontrei o professor de balé russo, produzida por B, conforme a interpretação de que o professor é russo, na pimeira gravação

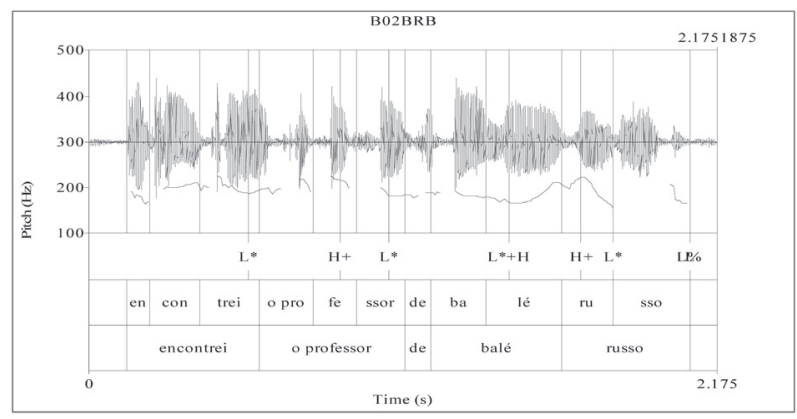

Fonte: Elaboração própria.

Figura 7 - Contorno entoacional e forma de onda da sentença Encontrei o professor de balé russo, produzida por B, conforme a interpretação de que o professor é russo, na segunda gravação

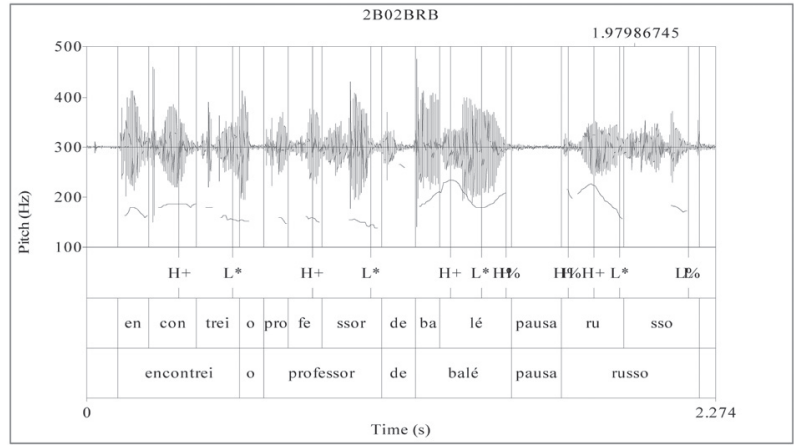

Fonte: Elaboração própria.

Ao se observar a figura (6), percebe-se que, na primeira gravação, na produção relativa à interpretação de que russo é o professor, a estratégia utilizada foi atribuir dois acentos tonais distintos para os vocábulos "balé" e "russo", dando pistas da formação de dois sintagmas fonológicos distintos para cada vocábulo. Ainda cabe notar que, na produção dessa sentença, também não se notou retração acentual na palavra "balé". Já ao se observar a figura (7), nota-se que, na segunda gravação da mesma sentença, a estratégia utilizada foi diferente da anterior: a informante preferiu fazer uma pausa para identificar que balé e russo estavam em sintagmas fonológicos diferentes, quando a intenção era dizer que russo era o professor. Na produção dessa sentença também não foi percebida retração acentual na palavra "balé". 
Quanto ao primeiro sentido requerido aos informantes para produção, ou seja, que o último vocábulo envolvido no contexto de choque acentual fizesse referência ao vocábulo imediatamente precedente, notou-se que, na produção desse sentido, o uso da retração de acento foi praticamente unânime pelas três informantes na realização das sentenças. Os resultados obtidos a partir da medição da duração das sílabas em contexto de choque acentual parecem indicar que a duração pode ser considerada um correlato acústico para a ocorrência ou não da retração de acentos, conforme a interpretação solicitada no desfazimento da ambiguidade das sentenças, pois as informantes realizaram elocuções diferentes para produzir cada um dos sentidos. ${ }^{9}$

A seguir, apresentamos alguns exemplos dos resultados das análises de duração das produções dos nossos informantes. Entretanto, cabe ressaltar que os resultados que serão apresentados carecem de tratamento estatístico. Portanto, as observações feitas a partir da análise dos dados se configuram como apontamento de tendências gerais, mas não como conclusões categóricas. Atentemo-nos à observação das Figuras 8 e 9.

Figura 8 - Tempo de duração da sílaba "cês" na sentença Eu vi o aluno de francês fraco, produzida por $\mathrm{P}$, conforme a interpretação de que o francês do aluno que é fraco

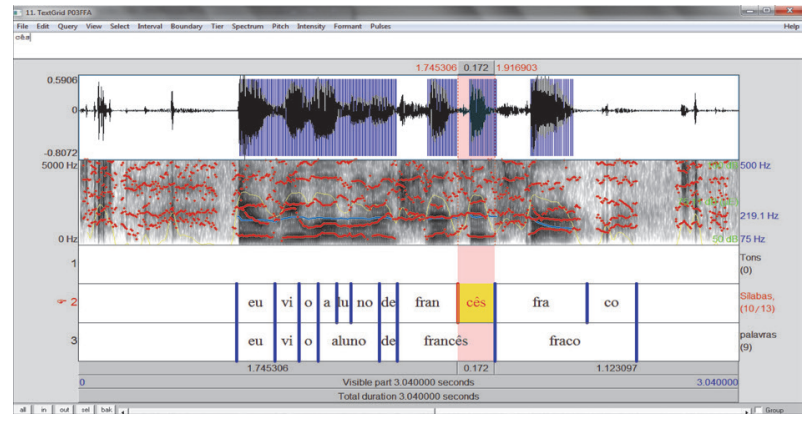

Fonte: Elaboração própria.

9 Conferir Tenani (2002) para resultados semelhantes para o correlato acústico "duração" na investigação da ocorrência ou não de degeminação em contexto de choque acentual em PB. 
Figura 9 - Tempo de duração da sílaba "cês" na sentença Eu vi o aluno de francês fraco, produzida por P, conforme a interpretação de que o aluno que é fraco

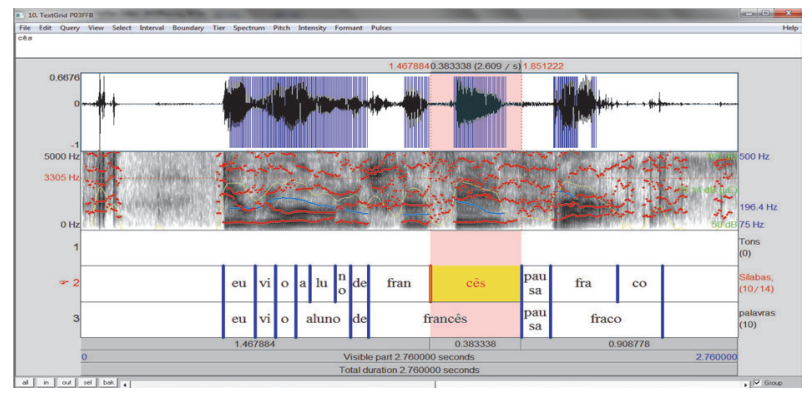

Fonte: Elaboração própria.

As Figuras 8 e 9 nos mostram interessantes resultados a respeito da duração das sílabas das palavras presentes no choque de acentos em cada interpretação solicitada. Na sentença "Eu vi o aluno de francês fraco", na qual as palavras "francês" e "fraco" se encontram em contexto de choque acentual, espera-se que, quando há retração de acento, a primeira sílaba da palavra "francês" seja a mais longa, uma vez que nela será implementado o acento; ${ }^{10}$ já quando não há retração, espera-se que a sílaba final da palavra "francês" tenha uma duração maior. Em relação a essa questão, pode-se dizer que nossa hipótese é confirmada, levando em conta as produções da informante P. Na produção da sentença Eu vi o aluno de francês fraco representada pela Figura 8, relativa à interpretação de que o francês é fraco, percebe-se retração acentual em " apresenta duração de 0,172s; na produção da mesma sentença, porém, conforme a interpretação de que o aluno é fraco (Figura 9), não se percebe retração em "francês" e a duração da mesma sílaba é maior $(=0,383 \mathrm{~s}) \cdot{ }^{11}$

Embora não possamos fazer afirmações categóricas, em termos de relevância estatística, sobre as diferenças de duração encontradas nos dados, cabe notar uma observação interessante sobre a diferença de duração atestada na primeira sílaba da palavra "francês" para as produções de P representadas pelas Figuras 8 e 9. Com a interpretação de que o francês é fraco (quando se percebe retração acentual), ou seja, a qualidade do francês que se sabe não é bom, a sílaba "fran" tem 0,277139s de duração, como pode ser observado mais claramente na Figura 10;

10 Sobre o fato de sílabas portadoras de acento possuírem maior duração do que sílabas não portadoras de acento, Massini-Cagliari (1992), entre outros.

11 Cabe notar que a sílaba "cês" da palavra "francês" da segunda leitura é produzida antecedendo uma pausa, o que pode também favorecer o aumento de duração de tal sílaba. 
já com a interpretação de que o aluno de francês é fraco (quando não se percebe retração acentual), a sílaba "fran" tem um valor de duração menor, de 0,259223s, como pode ser observado mais claramente na Figura 11.

Figura 10 - Tempo de duração da sílaba " fran" da palavra "francês" na sentença Eu vi o aluno de francês fraco, produzida por P, conforme a interpretação de que o francês do aluno que é fraco

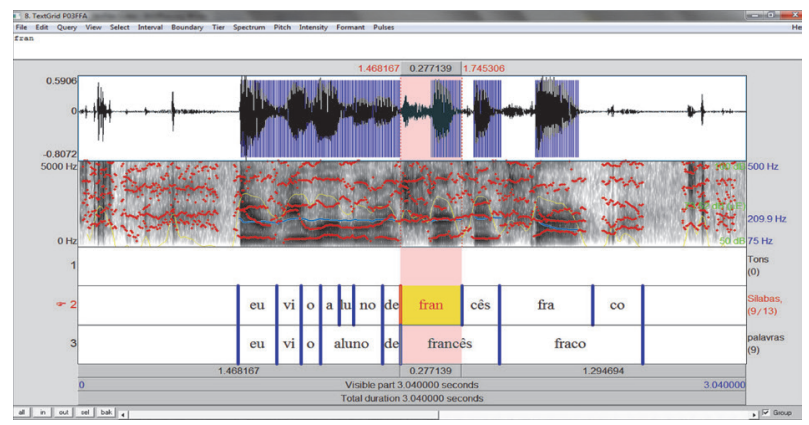

Fonte: Elaboração própria.

Figura 11 - Tempo de duração da sílaba "fran" na sentença Eu vi o professor de francês fraco, produzida por P, conforme a interpretação de que o aluno que é fraco

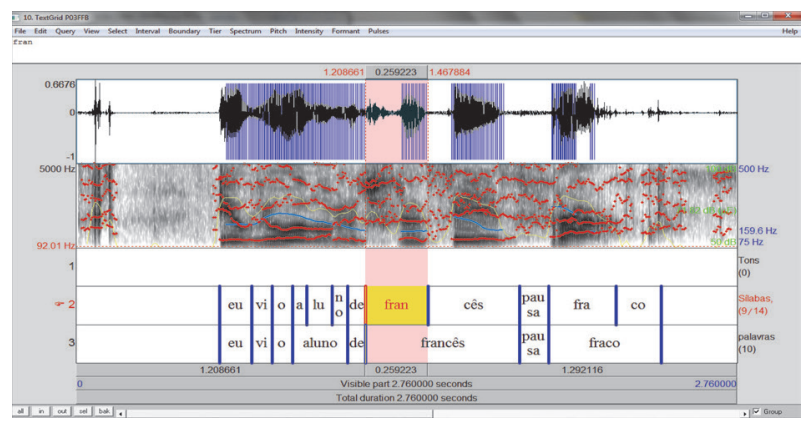

Fonte: Elaboração própria.

Quanto às duas outras informantes de nosso experimento de produção, B e L, assim como P, as duas primeiras também efetuaram a estratégia da retração de acento na produção da primeira interpretação solicitada, ou seja, aquela na qual a segunda palavra envolvida no choque acentual refere-se à palavra imediatamente precedente. 
Tendo como respaldo a aplicação das regras rítmicas (TAKEZAWA, 1981; SELKIRK, 1984), as quais estabelecem que o choque de acentos deve ser evitado para que apenas uma posição sobressaia na posição acentuada, o uso da estratégia de retração de acentos pelos informantes, no decorrer do experimento, foi encontrado, como previsto. Com relação ao domínio prosódico relevante para a ocorrência de retração acentual, é importante ressaltar que a língua portuguesa é sensível ao encontro acentual no nível do sintagma fonológico (ALBOUSALH, 1997; FROTA, 1995). Como se pode constatar, nossos resultados corroboram tais assertivas, uma vez que as três informantes realizaram espontaneamente a estratégia de retração de acento, em contexto de choque acentual no interior de sintagma fonológico, e a produziram sem que houvesse qualquer direcionamento para isso.

Os resultados encontrados foram praticamente categóricos para a aplicação da retração de acentos. Apenas em duas sentenças não obtivemos os resultados esperados. Mais adiante, especificaremos esses casos.

A seguir, apresentamos a tabela com os resultados para a aplicação da retração de acentos na produção da primeira interpretação solicitada aos informantes, ou seja, aquela na qual a segunda palavra envolvida no choque acentual refere-se à palavra imediatamente precedente:

Tabela 2 - Resultados do uso da estratégia de Retração de Acentos na produção da interpretação conforme a qual a segunda palavra envolvida no choque acentual refere-se à imediatamente antecedente

\begin{tabular}{ccccccc}
\hline Informante & \multicolumn{3}{c}{ Primeira Gravação } & \multicolumn{3}{c}{ Segunda Gravação } \\
\hline & $\begin{array}{c}\text { Sentenças } \\
\text { produzidas } \\
\text { com retração } \\
\text { de acentos }\end{array}$ & $\begin{array}{l}\text { Sentenças } \\
\text { produzidas } \\
\text { sem retração } \\
\text { de acentos }\end{array}$ & Total & $\begin{array}{l}\text { Sentenças } \\
\text { produzidas } \\
\text { com retração } \\
\text { de acentos }\end{array}$ & $\begin{array}{l}\text { Sentenças } \\
\text { produzidas } \\
\text { sem retração } \\
\text { de acentos }\end{array}$ & Total \\
\hline L & 14 & 1 & $\mathbf{1 5}$ & 14 & 1 & $\mathbf{1 5}$ \\
\hline B & 14 & 1 & $\mathbf{1 5}$ & 14 & 1 & $\mathbf{1 5}$ \\
\hline P & 15 & 0 & $\mathbf{1 5}$ & 15 & 0 & $\mathbf{1 5}$ \\
\hline & & & $\mathbf{4 5}$ & & & $\mathbf{4 5}$ \\
\hline
\end{tabular}

Fonte: Elaboração própria.

Duas sentenças produzidas por duas informantes "fugiram" do padrão apresentado em todas as outras produções para a primeira interpretação requerida e tiveram que ser excluídas do teste de percepção pelas razões que explicitaremos abaixo. 
A informante $(\mathrm{L})$ teve dificuldades em produzir a sentença $A$ gelatina ficou sobre o mocotó mole. Isto porque o alimento "mocotó" não fazia parte do conhecimento de mundo da informante. Essa situação fez com que a produção ficasse bem artificial, o que se refletiu nas análises acústicas. Diferentemente do que fez anteriormente, (L) não produziu a sentença "A gelatina ficou sobre o mocotó mole" de maneira a diferenciar, nas duas produções, as duas interpretações diferentes requeridas. Não se percebeu nenhuma estratégia prosódica de tentativa de diferenciação. Não houve produção de retração de acento, nem de pausa, nem atribuição de acentos tonais diferentes aos vocábulos envolvidos no choque acentual. As duas sentenças foram produzidas de maneiras bem parecidas.

Por sua vez, a informante (B) não apresentou dificuldades para produzir a sentença A gelatina ficou sobre o mocotó mole, mas teve resistência para produzir a sentença $O$ marinheiro deu um nó cego nos dois sentidos requeridos pelo experimento. Durante a gravação, percebeu-se que essa informante não conseguiu notar uma possível ambiguidade nessa sentença. Para ela, havia apenas um sentido: o nó que era cego e não teria como recuperar a informação de que o marinheiro era cego.

Através da observação das Figuras 11 e 12 abaixo, nota-se que, para produzir a sentença $O$ marinheiro deu um nó cego, a informante (B), apesar de ter usado a estratégia de pausas, não realizou diferenciação prosódica para as duas formas diferentes de interpretação dessa sentença. Como a informante não notou o sentido ambíguo que essa sentença poderia ter, acabou por reproduzir tal fato nas realizações da sentença.

Figura 12 - Imagem da representação acústica da sentença O marinheiro deu um nó cego, produzida por B, conforme a interpretação de que cego é o nó

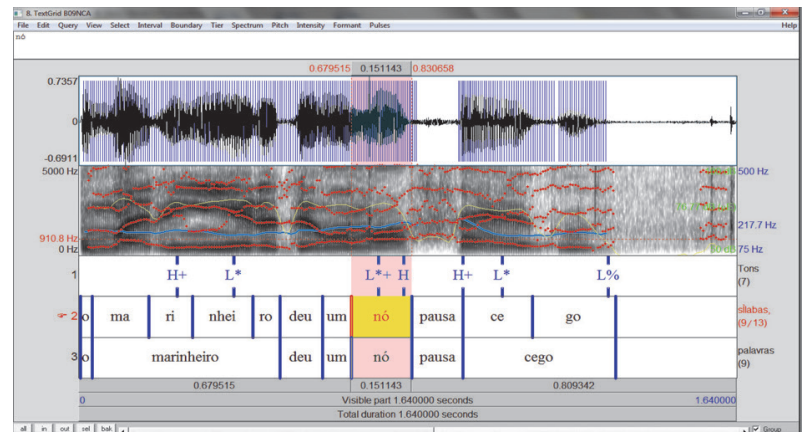

Fonte: Elaboração própria. 
Figura 13 - Imagem da representação acústica da sentença O marinheiro deu um nó cego, produzida por B, conforme a interpretação de que cego é o marinheiro

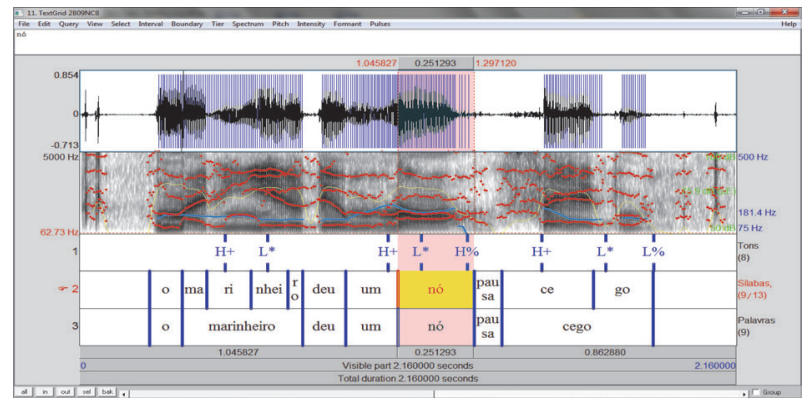

Fonte: Elaboração própria.

De maneira geral, o teste de produção nos mostrou que, ao terem consciência de que as sentenças eram ambíguas, as informantes se utilizaram de estratégias prosódicas diferentes na produção, para identificar cada um dos significados requeridos. Cabe ainda ressaltar que essas estratégias foram utilizadas de forma homogênea no decorrer de toda a realização do experimento. Mesmo depois de quatro meses, ao repetirmos o experimento, foram utilizadas as mesmas estratégias para as mesmas interpretações pelas informantes. Logo, os resultados obtidos da realização do teste de produção confirmam as hipóteses iniciais do nosso trabalho: a prosódia como forma de desambiguação. As informantes se utilizaram de estratégias como pausas e atribuição de acentos tonais para que o choque de acentos não se desfizesse por retração de acento, em produções em que o sentido requerido correspondia, em termos prosódicos, à formação de dois sintagmas fonológicos, como, por exemplo, em: Vi o professor de (balé) $\phi$ (russo) $\phi$. Já a retração de acentos ocorreu quando o sentido solicitado era o correspondente prosodicamente à formação de um único sintagma fonológico reestruturado para os dois vocábulos, como em (balé russo)ф.

Ainda sobre o fato de a duração poder ser um correlato acústico para a ocorrência ou não de retração acentual, cabe tecermos alguns comentários sobre o trabalho de Barbosa e Madureira (1999), o qual versa sobre essa temática, e compararmos com nossos resultados.

Barbosa e Madureira (1999) apresentam o PB como uma língua mista: língua de ritmo acentual (stress-timing) e língua de ritmo silábico (syllable-timing). Por ser mista, são necessários cuidados metodológicos na mensuração de durações segmentais. Ao tratar da duração, os autores apresentam o seguinte exemplo:

Zé diz se gabá I chapado e baixo. Zé diz se gaba I chapado e baixo. 
O segmento []] nas frases acima é mais alongado no primeiro enunciado (com o oxítono), quando recebe o grau de acentuação da sílaba acentuada que o precede imediatamente. Os segmentos [b] das palavras "gaba" e "gabá" não têm diferença de duração significativa. Portanto, o local da culminância acentual, conforme os autores, não é a sílaba fonológica. Para eles, a regra só parece ser quebrada em fronteira forte, como a da sequência "Zé diz se gabá. Chapado também." (em que "Chapado" é nome próprio e, nesse caso, não é alongado), (BARBOSA; MADUREIRA, 1999).

A partir desses dados experimentais, os autores afirmam que não há retração de acentos no PB, considerando o conceito de sílaba fonológica, uma vez que os resultados para a duração de "b" não demonstraram diferenças estatisticamente significativas. Ao contrário do que afirmam Barbosa e Madureira, nossos resultados, como pôde ser visto na discussão apresentada, demonstraram indícios de que a duração silábica e a retração de acentos estejam correlacionadas, ao menos nos casos específicos aqui estudados. É importante salientar que, nos dados apresentados, não focalizamos nossa análise apenas na duração da consoante presente na sílaba acentuada e na duração da consoante pós-acento, como fizeram Barbosa e Madureira, mas, sim, na duração total das sílabas envolvidas no choque de acento. Assim, quanto à duração das sílabas envolvidas no choque, nossos resultados dão pistas de que a duração pode ser um correlato acústico da retração de acentos em PB.

Após efetuar as análises do teste de produção, passamos para a segunda fase do experimento: o teste de percepção. Afinal, tem-se a necessidade de verificar se as estratégias prosódicas utilizadas na produção serão notadas e identificadas pelos ouvintes.

\section{Teste de percepção}

No teste de percepção, o objetivo principal foi averiguar se as estratégias prosódicas de desambiguação de sentenças, utilizadas pelos informantes no teste de produção, seriam percebidas e identificadas pelos ouvintes. As sentenças foram apresentadas para os informantes sem que esses tivessem a informação e/ ou confirmação de que eram sentenças ambíguas. Foi solicitado a cada um que, apenas pela percepção auditiva, identificasse qual o sentido que ele atribuía ao que estava sendo ouvido.

O experimento foi realizado com 10 informantes brasileiros, com curso superior em andamento e não pertencentes à área de Letras. A apresentação das sentenças ocorreu de forma aleatória, incluindo sentenças distratoras, para que o informante não tivesse conhecimento do fenômeno linguístico em análise. 
Tabela 3 - Resultados do experimento de percepção

\begin{tabular}{|c|c|c|}
\hline Sentenças & $\begin{array}{c}\text { Produzidas } \\
\text { COM retração } \\
\text { de acento e } \\
\text { interpretadas } \\
\text { de acordo com } \\
\text { a hipótese }^{10}\end{array}$ & $\begin{array}{c}\text { Produzidas } \\
\text { SEM retração } \\
\text { de acento e } \\
\text { interpretadas } \\
\text { de acordo com } \\
\underline{\text { a hipótese }}\end{array}$ \\
\hline 1- Assisti ao jornal hoje. & $80,00 \%$ & $100,00 \%$ \\
\hline 2 - Encontrei o professor de balé russo. & $100,00 \%$ & $90,00 \%$ \\
\hline 3 - Eu vi o aluno de francês fraco. & $90,00 \%$ & $80,00 \%$ \\
\hline 4 - Conheci a cantora da canção nova. & $70,00 \%$ & $80,00 \%$ \\
\hline 5 - Vi a Maria na TV muda. & $80,00 \%$ & $90,00 \%$ \\
\hline 6 - A gelatina ficou sobre o mocotó mole. & $80,00 \%$ & $40,00 \%$ \\
\hline 7 - Vi o garoto do cão bravo. & $100,00 \%$ & $70,00 \%$ \\
\hline 8 - O rapaz caiu no chão duro. & $100,00 \%$ & $80,00 \%$ \\
\hline 9 - O marinheiro deu um nó cego. & $100,00 \%$ & $10,00 \%$ \\
\hline 10 - Ela encontrou o gato no canal sujo. & $100,00 \%$ & $50,00 \%$ \\
\hline 11 - Ele bateu o cadeado no portão torto. & $100,00 \%$ & $80,00 \%$ \\
\hline 12 - O menino escreveu no papel pardo. & $90,00 \%$ & $100,00 \%$ \\
\hline 13 - Ele encontrou o vendedor de sofá persa. & $100,00 \%$ & $80,00 \%$ \\
\hline 14 - Joana achou o musculoso de fé forte. & $80,00 \%$ & $70,00 \%$ \\
\hline 15 - João acudiu o marajá branco. & $100,00 \%$ & $80,00 \%$ \\
\hline MÉDIA & 91,3 & 73,3 \\
\hline DESVIO PADRÃO & 10,6 & 23,8 \\
\hline
\end{tabular}

Fonte: Elaboração própria.

De maneira geral, pode-se dizer que os resultados obtidos vão ao encontro das teorias dos princípios de alternância rítmica (SELKIRK, 1984). Em contexto de choque acentual, a retração de acento foi dominante na gramática fonológica dos informantes do teste de percepção, os quais não apresentaram qualquer dificuldade em associar os vocábulos analisados como um único grupo prosódico,

12 Conferir hipótese na seção "Introdução". 
ou seja, conforme a interpretação de que o último vocábulo envolvido no choque acentual estaria relacionado ao vocábulo imediatamente anterior. Isso pode ser afirmado com base nos dados da Tabela 3 acima, uma vez que, para as sentenças produzidas com retração acentual, a porcentagem mais baixa de identificação de interpretação conforme a qual o último vocábulo envolvido no choque acentual referia-se imediatamente ao precedente foi de 70\%. Cabe ainda notar que a proximidade entre os vocábulos é algo que também poderia influenciar a interpretação dos ouvintes. Isto posto, a metodologia adotada para a realização do experimento foi bastante cautelosa, para tentar evitar a associação do sentido pela proximidade.

Um indício de que obtivemos êxito na metodologia utilizada foram os resultados alcançados para as interpretações das sentenças produzidas sem retração de acentos. Na produção das sentenças cuja interpretação relacionavase à não referência do segundo vocábulo envolvido no choque acentual com o vocábulo imediatamente precedente, as informantes utilizaram-se principalmente de duas estratégias prosódicas: pausas e atribuição de acentos tonais distintos a cada uma das sílabas tônicas dos vocábulos. No teste de percepção, observou-se que as sentenças produzidas com essas estratégias prosódicas foram identificadas pelos ouvintes, na sua maioria, como correspondendo ao sentido pretendido pelas informantes do teste de produção, na produção de tais estratégias.

Na tabela acima, identificamos, através do sombreado de fundo, 3 sentenças problemáticas. Na verdade, a sentença 10, Ela encontrou o gato no canal sujo, não chegou a ser de fato um "problema". Destacamos a sentença em questão porque metade dos informantes apresentou dificuldades de interpretar a palavra "sujo" como referente ao "gato". Isso nos levou a suspeitar que essa sentença foi associada pelas ouvintes a um único sentido, segundo o qual o vocábulo "sujo" referia-se à "canal". Um informante até completou: "o gato até poderia ficar sujo, mas porque o canal estava sujo" (EC, 33 anos).

Após o comentário desse informante, desconfiou-se que o problema estivesse ligado mais ao tipo de emprego da palavra canal realizado mais comumente pelos falantes do experimento de percepção. Suspeitamos que, para esses falantes, o vocábulo "canal" já estaria previamente associado a lugar sujo, carregando este atributo de maneira implícita. Para comprovar essa hipótese, gravou-se uma sentença semelhante, nomeadamente, Ela encontrou o gato no quintal sujo, apresentando as mesmas estratégias prosódicas utilizadas pelas informantes para cada interpretação desejada. Ao substituirmos a palavra canal pela palavra quintal, o resultado se fez bem diferente do anterior: 
Tabela 4 - Resultados do experimento de percepção para a sentença: Ela encontrou o gato no quintal sujo x Ela encontrou o gato no canal sujo

\begin{tabular}{lll}
\hline Sentenças & $\begin{array}{l}\text { Produzidas COM retração } \\
\text { de acento e interpretadas } \\
\text { de acordo com a hipótese }\end{array}$ & $\begin{array}{l}\text { Produzidas SEM retração } \\
\text { de acento e interpretadas } \\
\text { de acordo com a hipótese }\end{array}$ \\
\hline $\begin{array}{l}10 \text { - Ela encontrou o gato } \\
\text { no canal sujo. }\end{array}$ & $100,00 \%$ & $50,00 \%$ \\
\hline $\begin{array}{l}16 \text { - Ela encontrou o gato } \\
\text { no quintal sujo. }\end{array}$ & $80,00 \%$ & $100,00 \%$ \\
\hline
\end{tabular}

Fonte: Elaboração própria.

O resultado obtido para a sentença 16 não foi agrupado junto aos demais resultados, porque o problema com o vocábulo "canal", relacionado ao uso desse vocábulo pelos informantes do teste de percepção, como algo "naturalmente sujo", só foi identificado após a realização do teste de produção. A gravação de uma nova sentença, substituindo este vocábulo, foi feita apenas com uma informante, ciente dos fenômenos a serem investigados, com o objetivo único de averiguarmos nossa hipótese de que a interpretação não ambígua pelos ouvintes do teste de percepção para a sentença 10 se devia, de fato, ao uso da palavra "canal".

Já as outras duas sentenças marcadas na tabela 3, sentenças 6 e 9, foram verdadeiramente problemáticas para o experimento.

A sentença 6, A gelatina ficou sobre o mocotó mole, apresentou duas dificuldades bastante peculiares: (1) o desconhecimento de alguns dos informantes da existência do alimento "mocotó" e (2) o efeito semântico inesperado da mistura de "gelatina" com "mocotó", gerando estranheza para parte dos informantes. Essas peculiaridades fizeram com que a artificialidade da sentença chegasse ao ponto de comprometer os resultados obtidos do experimento para essa sentença. A existência de algo tão incomum e fora da realidade dos falantes do experimento levou-os a uma interpretação que lhes parecesse menos estranha. Um dos comentários fornecido por uma informante, ao analisar essa sentença, foi: "hum... essa tá difícil, não entendi muito bem. Bom, de toda a forma, a gelatina é mais mole, né?! Então, é a gelatina que ficou mole e não o mocotó" (RC, 30 anos).

O problema da sentença 9, O marinheiro deu um nó cego, é ainda mais complexo, por isso uma porcentagem tão baixa para uma das interpretações 
esperadas (10\%). A dificuldade de interpretar essa sentença como ambígua se encontra na escolha dos vocábulos "nó" e "cego". "Nó cego" é uma expressão cristalizada na língua portuguesa e tanto o experimento de produção quanto o experimento de percepção demonstraram que, para expressões cristalizadas, o princípio de alternância rítmica está ainda mais presente. A presença de um monossílabo tônico (no caso, nó) não foi identificada como uma das causas do problema dessa sentença, pois, se assim o fosse, a sentença 14, Joana encontrou o musculoso de fé forte, também deveria apresentar alguma dificuldade nesse aspecto.

Há ainda que se ressaltar que as duas últimas sentenças aqui discutidas também apresentaram dificuldades para as informantes no teste de produção. Além disso, sintaticamente há algo em comum entre elas: um dos sentidos requeridos para essas sentenças exigia que o informante relacionasse o último vocábulo ao sujeito da sentença e não a outras partes do predicado, como a maioria das construções das sentenças anteriores. Isto é, o referente estava bastante distante, logo, mais difícil para recuperar o sentido. Essa hipótese apresenta-se bastante plausível, uma vez que estamos no âmbito da interface sintaxe-fonologia. Acreditamos que essa hipótese deva ainda ser mais bem analisada futuramente. Mas, ao mesmo tempo, para esse experimento, temos indícios de que esse aspecto sintático não é determinante para a não interpretação da ambiguidade e de que o problema com essas sentenças seja mesmo mais de contexto de uso, no caso da sentença 6, e pela presença de expressão cristalizada, na sentença 9. Isso porque não podemos deixar de levar em consideração a sentença 15, João acudiu o marajá branco, na qual um dos sentidos possíveis seria "o João, branco de susto, acudindo o marajá". Da mesma forma que nas sentenças aqui discutidas, um dos sentidos da sentença 15 fazia referência a um termo distante, identificado como sujeito da oração, e a interpretabilidade dessa sentença, nesse sentido desejado, apresentou um bom índice de aceitação pelos informantes (80\%).

Após as explicitações, reapresentaremos a Tabela 3, (agora como Tabela 5) sem as 3 sentenças problemáticas acima mencionadas. É importante notar que, ao retirá-las, o desvio padrão da segunda coluna cai consideravelmente (de 23,8 na Tabela 3 para 9,8 na Tabela 5). Isso ressalta a discrepância que essas sentenças trazem para os dados, tornando nossas hipóteses ainda mais evidentes: 
Tabela 5 - Resultados do experimento de percepção

\begin{tabular}{lcc}
\hline Sentenças & $\begin{array}{c}\text { Produzidas } \\
\text { COM retração } \\
\text { de acento e } \\
\text { interpretadas } \\
\text { de acordo com } \\
\text { a hipótese }\end{array}$ & $\begin{array}{c}\text { Produzidas } \\
\text { SEM retração } \\
\text { de acento e } \\
\text { interpretadas } \\
\text { de acordo com } \\
\text { a hipótese }\end{array}$ \\
\hline 1- Assisti ao jornal hoje. & $80,00 \%$ & $100,00 \%$ \\
\hline 2 - Encontrei o professor de balé russo. & $100,00 \%$ & $90,00 \%$ \\
\hline 3 - Eu vi o a aluno de francês fraco. & $90,00 \%$ & $80,00 \%$ \\
\hline 4 - Conheci a cantora da canção nova. & $70,00 \%$ & $80,00 \%$ \\
\hline 5 - Vi a Maria na TV muda. & $80,00 \%$ & $90,00 \%$ \\
\hline 7 - Vi o garoto do cão bravo. & $100,00 \%$ & $70,00 \%$ \\
\hline 8 - O rapaz caiu no chão duro. & $100,00 \%$ & $80,00 \%$ \\
\hline 11 - Ele bateu o cadeado no portão torto. & $100,00 \%$ & $80,00 \%$ \\
\hline 12 - O menino escreveu no papel pardo. & $90,00 \%$ & $100,00 \%$ \\
\hline 13 - Ele encontrou o vendedor de sofá persa. & $100,00 \%$ & $80,00 \%$ \\
\hline 14 - Joana achou o musculoso de fé forte. & $80,00 \%$ & $70,00 \%$ \\
\hline 15 - João acudiu o marajá branco. & $100,00 \%$ & $80,00 \%$ \\
\hline MÉDIA & 90,8 & 8,8 \\
\hline DESVIO PADRÃo & 10,8 & \begin{tabular}{c} 
ho $\%$ \\
\hline
\end{tabular} \\
\hline
\end{tabular}

Fonte: Elaboração própria.

\section{Considerações finais}

Neste trabalho, mostramos que a desambiguação de sentenças ambíguas, pela prosódia, pode interferir na aplicação das regras rítmicas. O choque de acentos entre dois vocábulos subsequentes é desfeito por retração de acento, quando o intuito é produzir um sentido em que esses dois vocábulos possam formar um único sintagma fonológico, como em O menino escreveu no (papel pardo) $\Phi$. Entretanto, na produção de uma sentença com o intuito de se ter uma interpretabilidade conforme a qual a palavra "pardo" é que foi escrita em um

13 Conferir hipótese na seção "Introdução". 
papel, os informantes utilizaram estratégias prosódicas diferentes da retração acentual. Nesse caso, as estratégias mais utilizadas foram: pausa entre as duas palavras envolvidas no contexto de choque acentual ou a atribuição de acentos tonais diferentes a cada uma das palavras envolvidas nesse mesmo contexto.

Os resultados do teste de percepção corroboraram os resultados obtidos a partir da aplicação do teste de produção. Os falantes do teste de percepção identificaram que uma mesma sentença, ao ser apresentada pela segunda vez, era realizada de forma diferente da primeira. Mesmo sem ter qualquer informação sobre a ambiguidade que poderia haver nas sentenças escutadas, os sujeitos do teste de percepção, ao se deparem com slides que repetiam uma sentença já vista, notaram que, mesmo sendo a mesma sentença, a forma de realização era diferente. Além de perceberem essa diferença prosódica de realização da mesma sentença, os informantes correlacionaram as diferentes realizações prosódicas a interpretabilidades semânticas também diferentes. Mais de 80\% dos casos analisados coincidiram com a hipótese apresentada neste trabalho.

\section{Agradecimentos}

Agradecemos às professoras Maria Bernadete Marques Abaurre e Luciani Ester Tenani pelas sugestões e críticas feitas a versões preliminares deste trabalho e ao apoio das seguintes agências de fomento: FAPESP (processo 2011/50044-9) e FCT (PTDC/CLE-LIN/119787/2010).

GRAVINA, A. P.; FERNANDES-SVARTMAN, F. Syntax-phonology interface: disambiguation by prosodic structure in Brazilian Portuguese. Alfa, São José do Rio Preto, v.57, n.2, p.639-668, 2013.

- ABSTRACT: This paper aims to analyze prosodic strategies of disambiguation of Brazilian Portuguese (henceforth, BP) sentences in the context of syntactic ambiguity and stress clash. Our hypothesis is that the disambiguation of these sentences happens through different prosodic strategies to undo the stress clash. To test this hypothesis, experiments of production and perception were carried out with BP speakers. The results were analyzed in light of the Prosodic Phonology (NESPOR; VOGEL, 1986) and the Intonational Phonology (PIERREHUMBERT, 1980; LADD, 1996, 2008). Our results show that: (i) when there is retraction of the stress, there are clues to the formation of only one phonological phrase and the interpretation is that the second word involved in the clash refers to the immediately preceding word; (ii) on the other hand, when the undoing of the stress clash is done by pauses or the association of a pitch accent with every word involved in the stress clash, there are clues to the formation of two phonological phrases and the interpretation obtained is that the second word on the clash context refers not to the immediately preceding word, but to the other in the sentence.

- KEYWORDS: Stress Clash. Syntax-Phonology Interface. Prosody. Brazilian Portuguese. 


\section{REFERÊNCIAS}

ABOUSALH, E. F. Resolução de choques de acento no português brasileiro: elementos para uma reflexão sobre interface sintaxe-fonologia. 1997. 157 f. Dissertação (Mestrado em linguística) - Instituto de Estudos da Linguagem, Universidade Estadual de Campinas, Campinas, 1997.

BARBOSA, A.; MADUREIRA, S. Toward a hierarchical model of rhythm production evidence from phrase stress domains in Brazilian Portuguese. In: XIV INTERNATIONAL CONGRESS OF PHONETIC SCIENCES, 14, 1999, San Francisco. Proceedings... San Francisco, 1999. p.225-230.

BECKMAN, M.; PIERREHUMBERT, J. Intonational Structure in Japanese and English. Phonology Yearbook, Cambridge, n.3, p.255-310, 1986.

BOERSMA, P.; WEENINK, D. Praat: doing phonetics by computer. Version 5.2.07. [Computer Program], 2010. Disponível em: <http//:www.praat.org>. Acesso em: 22 jun. 2011.

FERNANDES, F. Ordem, focalização e preenchimento em português: sintaxe e prosódia. 2007. 415f. Tese (Doutorado em linguística) - Instituto de Estudos da Linguagem, Universidade de Campinas, Campinas, 2007.

FROTA, S. Os domínios prosódicos e o português europeu: fenómenos de sandhi. In: ENCONTRO NACIONAL DA APL, 10, Évora, 1994. Actas... Lisboa: APL, 1995. p.221-238.

FROTA, S.; VIGÁRIO, M. Aspectos de prosódia comparada: ritmo e entoação no PE e no PB. In: ENCONTRO NACIONAL DA ASSOCIAÇÃO PORTUGUESA DE LINGUÍSTICA, 15, Coimbra, 2000. Actas... Coimbra: APL, 2000. p.533-555.

GHINI, M. $\phi$-formation in italian: a new proposal. In Carrie Dyck (ed.), Toronto Working Papers in Linguistics, vol.12, $\mathrm{n}^{\circ}$ 2. Department of Linguistic, University of Toronto, 1993, p.41-78.

JUN, S. A. Prosodic typology. the phonology of intonation and phrasing. New York: Oxford University Press, 2005.

LADD, D. R. Intonational phonology. 2.ed. Cambridge: CUP, 2008. Intonational phonology. Cambridge: CUP, 1996.

LIBERMAN, M.; PRINCE, A. On stress and linguistic rhythm. Linguistic Inquiry, Massachusetts, v.8, p.249-336, 1977.

MASSINI-CAGLIARI, G. Acento e ritmo. São Paulo: Contexto, 1992.

NESPOR, M.; VOGEL, I. On clashes and lapses. Phonology, Cambridge, n.6, p.69116, 1989. 
. Prosodic phonology. Foris: Dordrecht. 1986.

. Prosodic domains of external sandhi rules. In: DER HURST, V.; SMITH, N. (Eds.). The structure of phonological representations. Dordrecht: Foris Publicatoins. 1982. p.225-255.

PIERREHUMBERT, J. The phonology and phonetics of English intonation. 1980. $201 \mathrm{f}$. Tese (Doutorado em Filosofia) - Department of Linguistics and Philosophy, Massachesetts Institute of Technology, Massachesetts, 1980.

SÂNDALO, F.; TRUNKENBRODT, H. Some notes on phonological phrasing in Brazilian Portuguese. The MIT Working Paper, Cambridge, v.42, p. 285-310, 2002.

SANTOS, R. S. Categorias sintáticas vazias e retração de acento em português brasileiro. D.E.L.T.A., Porto Alegre, v.18, n.1, p.67-86, 2002.

SELKIRK, E. Phonology and sintax. The relation between sound and structure. Cambridge: The MIT Press, 1984.

SELKIRK, E. On derived domains in sentence phonology. Phonology Yearbook, Cambridge, n.3, p.371-405, 1986.

SELKIRK, E.; SHEN,T. Prosodic domain in shanghai Chinese. In: INKELAS, S.; ZEC, D. (Org.). The phonology-syntax connection. Chicago: The University of Chicago Press, 1990, p.313-337.

SELKIRK, E.; TATEISHI, K. Syntax and downstep in Japanese. In: GEORGOPOLOUS, C.; ISHIHARA, R. (Eds). Interdisciplinary approaches to language: Essays in honor of S. Y. Kuroda: Kluwer, 1991. p.519-543.

TAKEZAWA, K. Rhythm rule in metrical theory. Linguistic Analysis, Elsevier North Holland, v. 8, n. 1, p.1-14, 1981.

TENANI, L. Domínios prosódicos no português do Brasil: implicações para a prosódia e para a aplicação de processos fonológicos. 2002. 317f. Tese (Doutorado em linguística) - Instituto de Estudos da Linguagem, Universidade Estadual de Campinas, 2002.

Recebido em outubro de 2011

Aprovado em novembro de 2012 